da possibilidade de um conhecimento efetivo. Sabedoria do nunca, o primeiro livro da trilogia, é uma sintese dos diários que escrevi de 1983 até 1994. Neles ruminei minha falta de lugar e a oscilação dolorosa entre o desejo de pertencer ao trem e o terror de um dia fazer parte dele. Eram o estranhamento e a dor uma doença psiquiátrico-psicológica ou delatavam o caráter claustrofóbico das cabines? Impedido de ultrapassar essa indecisão, o livro afirma a dor, o negativo e o suicidio como os abrigos diante do ofuscamento do trem. O segundo livro, Ignorancia do sempre, é um livro de transiçāo. Nele a dor já não noticia o fracasso em obter lugar nos assentos do trem, mas começa a aparecer como a protetora e a guardiã do olho da nuca. No terceiro livro, Certeza do agora, o olho da nuca já está bem aberto, já olhou para dentro da dimensão real e é a partir de lá que desmascara e ultrapassa o regime que vigora nos compartimentos. Ali jả não há mais dúvida: o homem sem o olho-de-trás é um títere do trem e a vida nos compartimentos é apenas a execuçāo de um roteiro predisposto pela própria organização do trem, organização essa que destrói e bloqueia o surgimento do rosto humano.

\section{MINHA CEGUEIRA}

\author{
Bernardo Carvalho'
}

\section{D} costuma ser um sinal de burrice. Sempre fui uma nulidade em matemática. Só consegui aprender a multiplicar no dia em que, como uma luz, ouvi a frase "a vezes $b$ " e afinal a compreendi pela semântica, quando traduzi numa equaçāo gramatical o que até entāo era uma abstraçāo incompreensível. A literatura, para mim, é essa transposiçāo. É uma forma de superar uma falha e uma impossibilidade, pela imaginaçāo.

As minhas narrativas são formas de imaginar o que nāo consigo entender. Sāo formas de suprir a minha incapacidade de abstraçāo. A literatura passa a ser uma "formulação de idéias". Quando falo em "formulação de idéias" nāo estou me referindo à fiç̧āo reduzida a meio para transmitir as idéias do autor, com8 no tradicional "romance de idéias", mas à literatura como uma forma de pensar para quem nāo consegue pensar de outra forma. Não tem nada a ver com a ilustração das idéias prévias do autor. Nem com uma escrita calculista e fria, mas com a conversāo de sentimentos e emoçōes em uma forma de pensar. Uma espécie de mitologia da razāo, como se isso fosse possível. Daí talvez o meu gosto por aberraçōes e paradoxos. Os próprios livros são as idéias. É na própria literatura que elas se manifestam e ganham forma.

Costumo buscar essa forma pela constituição de um (outro) mundo e de uma (outra) visāo de mundo. E daí que não hả muito espaço para o naturalismo no que eu escrevo. Tanto faz se os personagens falam a "língua da rua" ou não, tanto faz se têm verossimilhança psicológica ou não, tanto faz se sāo "de papel" ou nāo. Porque, no fundo, todos os personagens, por mais psicologicamente verossímeis, sāo sempre "de papel" e a "língua da rua", uma vez escrita, não passa de um artifício literário como qualquer outro.

$\dot{E}$ aí que eu bato de cabeça com uma tendência cíclica na literatura brasileira, e que hoje me parece estar se tornando de novo um paradigma. No Brasil, é comum

' Nasceu no Rio de Janeiro, em 1960. Publicou Aberraçāo (1993), Onze (1995), Os bébados e os sonambulos (1966), Teatro (1998), As iniciais (1999), Nove noites (2002, prêmio Jabuti), Magnólia (2003, prêmio Jabuti, APCA). Trabalha como jornalista na Folha de S.Paulo. 
tratar a literatura como documento histórico ou sociológico. E privilegiar a literatura que mais se presta a isso. A fragilidade da identidade nacional dificulta a compreensão das obras separadas de uma tendência ou movimento. Como se à literatura coubesse suprir uma falta social. Há uma tradiçāo predominante de analisar, muitas vezes reduzindo, a literatura como reflexo da sociedade, de fazer da literatura a carteira de identidade dessa sociedade. As deficiências da malha social no Brasil criam má-consciência e reduzem as chances de uma compreensāo da literatura nāo como produto independente da sociedade em que é criada (o que seria impossivel), mas, partindo dessa obviedade (que toda literatura é conseqüência do lugar e do tempo em que é criada), de entendè-la mais como possibilidade de invenção do que como documento histórico e sociológico, que de qualquer maneira ela sempre é, a priori.

As carências sociais no Brasil são transferidas pela má-consciência para a produção artística e isso determina um tipo de crítica, um tipo de olhar, e valoriza um tipo de literatura, criando também alguns cacoetes tanto na leitura como na produçāo literária. As consequências sāo diversas e podem ser devidamente analisadas por gente mais competente do que eu. O que me interessa sāo os vicios que esse ponto de vista pode disseminar entre os escritores: passa a ser considerada desprezível a literatura na qual não se reconhece de imediaro a sociedade ou o momento histórico, a ponto de muita gente não perceber mais que a literatura já é o momento histórico, ou melhor, que ela também faz o momento histórico, e nāo apenas o fotografa. É essa, no fundo, a graça de toda criação que se preza.

A tendência predominante de apreender a literatura como documento acabou introjetando uma distorção entre os autores. A recorrência da valorização da "voz das ruas" é resultado disso. E até os mais esclarecidos acabam sofrendo a influência. É possível perceber que partem de um substrato comum, procuram uma autenticidade bruta contra os artifícios literários (que, em geral, associam a uma elite culta e caricaturalmente alienada da realidade social, uma elite parnasiana), se recusando a ver na sua própria autenticidade militante qualquer tipo de artificio. Conforme o grau de esclarecimento desses autores, eles podem ser tanto ingênuos como hipócritas.

O populismo e o naturalismo são traços tão reincidentes na literatura brasileira quanto o beletrismo. Num país inculto e de injustiças sociais tão graves, onde os homens da cultura volta e meia sāo tentados a transferir a culpa para a arte, o naturalismo surge como uma espécie de redençã̃o. Por uma compreensivel distorçāo, falar a "voz das ruas" na literatura, por mais idealizada e construida que ela seja, passa a ser sinônimo da verdade, de engajamento político e de justiça social, sobretudo nos momentos em que a injustiça e a desigualdade se tornam mais escandalosas e estarrecedoras. É como dar voz aos oprimidos e aos injustiçados. $\mathrm{Na}$ maioria dos casos, porém, o que se produz com as boas intençōes e a má-consciência é uma mistificaçāo que, por um lado, nāo resolve injustiça nenhuma e, por outro, cerceia as possibilidades da criação literária. Afinal, o mais extraordinário na literatura é justamente o poder de criar diferenças e desvios, de tomar caminhos inesperados e imprevistos, em vez de seguir regras.
É importante deixar bem claro que nāo me oponho (nem poderia) à manifestaçāo da realidade, da violència, dos oprimidos e dos injustiçados na literatura. Até porque, de certo modo, é isso o que a literatura na qual acredito manifesta ao criar diferenças e desvios. Ela amplia a realidade. Abre novas possibilidades de compreensão da realidade, em vez de se contentar com uma só, consensual ou majoritária. Mas é difícil engolir a impostura que pretende que uma determinada manifestaçăo literária seja imediata e espontânea, e por isso mais verdadeira, pois seria aceitar o retrocesso proposto por quem subjuga a literatura, em última instância, ao relato, ao depoimento, ao documental, como se a invenção fosse secundária. Tudo em literatura é criaçāo, do aparente documento à ficçāo mais inverossimil.

O mais curioso é que esse naturalismo também norteia autores das novas geraçōes que procuram falar de si com maior veracidade. É o eu a falar o equivalente idealizado da "voz das ruas", tāo mais "autêntico" quanto mais violentas forem as suas experiēncias. Em alguns casos, a "invençāo" não passa de um verniz ou de um efeito publicitário. Para esses autores, a idéia de que a literatura é sempre artifício é um absurdo a ser combatido (porque os desarma), quando muito uma frescura restrita a uma elite intelectual ou artística que, como boa parte da elite econômica do país, viveria fora da realidade. Por uma curiosa inversão, passa a haver um isomorfismo entre a violência social e a óptica desse eu encurralado a olhar para o próprio umbigo, como se bastasse vomitar a expressão de si para combater a hipocrisia que o cerca.

O desencanto com esse tipo de naturalismo militante ou oportunista está de alguma maneira na origem dos meus livros. Todos eles dão a entender, de um jeito ou de outro, que vivemos num mundo cujo entendimento é sempre uma convençāo, que parece dar sentido a tudo, quando no fundo é apenas um artifício cambiável E essa a sua militância: as convençōes sāo criadas pelas necessidades do mundo; cabe aos homens criar novas necessidades e refletir sobre elas, pela ciência e pela arte, em vez de apenas espelhá-las e satisfazê-las.

Em Teatro, o que podia ser criticado na resolução totalmente fechada, "matemática" e articulada do romance era, no fundo, o próprio tema do livro. Nesse romance, devo ter chegado à forma mais manifesta - e por isso talvez também a mais esquemática - dessa idéia do mundo como convençāo, que foi sendo afinada em As iniciais e Medo de Sade. Em Nove noites, ela já nāo está tão aparente. Antes, aparecia na estrutura narrativa e nas frases que se desdobravam e se contradiziam, esfacelando o mundo que acabava de ser construído. Agora, foi diluída em frases mais lineares e integrada ao próprio enredo. Tudo isso, é claro, nāo é programado e pode mudar da noite para o dia. Não há regras. Posso voltar ao que já fiz ou seguir por caminhos que desconheço. Nāo me sinto escrevendo dentro de uma camisa-de-força. De qualquer jeito, como disse no início, o que eu vejo nos meus livros nāo é o que as outras pessoas vêem. Mais uma razão para nāo confiar no que tenho a dizer sobre eles.

Este texto foi escrito hả dois anos, 